\title{
PENGARUH PEMBERIAN DAUN KELOR TERHADAP PENURUNAN TEKANAN DARAH PADA PENDERITA HIPERTENSI LANSIA SELAMA MASA PANDEMI COVID-19
}

\section{THE EFFECT OF MORINGA OLEIFERA LEAF ON BLOOD PRESSURE REDUCTION IN ELDERLY WITH HYPERTENSION PATIENTS DURING THE COVID-19 PANDEMICS}

\author{
Wahyu Riniasih ${ }^{\varpi}$, Wahyu Dewi Hapsari \\ Dosen Universitas An Nuur, JIn.Gajah Mada No.07,Purwodadi, Grobogan. Indonesia \\ Correspondence Email : wahyuannur83@gmail.com
}

\begin{abstract}
ABSTRAK
Hipertensi menjadi salah satu penyakit yang menjadi faktor risiko terbesar kematian. Hipertensi menjadi penyakit penyerta yang banyak di temukan pada penderita COVID-19. Sekitar 15\% kasus hipertensi yang terdapat pada pasien COVID-19 dan kejadian hipertensi mayoritas terjadi pada usia lansia sebesar 54,60\%. Diperlukan suatu tindakan non farmakologi untuk menurunkan tekanan darah salah satunya dengan daun kelor. Tujuan penelitian ini untuk mengetahui pengaruh pemberian daun kelor terhadap penurunan tekanan darah pada penderita hipertensi lansia selama masa pandemi covid -19 di Kabupaten Grobogan. Metode penelitian kuantitatif dengan rancangan quasy eksperimen with control group design. Pengambilan sampel adalah non probability sampling dengan teknik qouta sampling (Judgement Sampling). Hasil diperoleh rata rata penurunan tekanan darah sistole adalah 16,00 dan hasil signifikansi dari perbedaan didapatkan $\rho(0,000)<\alpha$ $(0,05)$. rata-rata penurunan tekanan darah diastole adalah 14,33 dengan hasil signifikansi dari perbedaan didapatkan $\rho$ $(0,000)<\alpha(0,05)$ yang artinya ada pengaruh pemberian daun kelor terhadap penurunan tekanan darah. Simpulan terdapat perbedaan penurunan tekanan darah pada kelompok perlakuan dan kelompok kontrol pada lansia hipertensi di kabupaten Grobogan.
\end{abstract}

Kata Kunci : hipertensi; lansia; daun kelor.

\section{ABSTRACT}

Hypertension is one of the diseases that are the biggest risk factor for death. Hypertension is a comorbid disease that is often found in patients with COVID-19. About 15\% of hypertension cases found in COVID-19 patients and the majority of hypertension cases occurred in the elderly at 54.60\%. A non-pharmacological action is needed to lower blood pressure, one of which is Moringa Oleifera leaves. The purpose of this study was to determine the effect of giving Moringa Oleifera leaves on reducing blood pressure in elderly hypertensive patients during the COVID-19 pandemic in Grobogan Regency. Quantitative research method was used with a quasi-experimental design control group design. The sampling technique was Non Probability Sampling with Qouta Sampling technique (Judgement Sampling). The results obtained that the average decrease in systolic blood pressure was 16.00 and the significance of the difference was $\llbracket(0.000)(0.05)$. The average decrease in diastolic blood pressure was 14.33 with the results of the significance of the difference obtained $(0.000)(0.05)$ which means that there is an effect of giving Moringa Oleifera leaves to decrease blood pressure. In conclusion, there are differences in blood pressure reduction in the treatment group and the control group in the elderly with hypertension in Grobogan district.

Keywords: hypertension, elderly, moringa leaf. 


\section{PENDAHULUAN}

Hipertensi adalah suatu peningkatan abnormal tekanan darah dalam pembuluh darah arteri secara terus menerus. Hipertensi menjadi salah satu penyakit yang menjadi faktor risiko terbesar kematian (Nuranti et al., 2020). Faktor-faktor yang menjadi penyebab terjadinya hipertensi antara lain toksin, faktor genetik, umur, jenis kelamin, etnis, stress, kegemukan, nutrisi, merokok, narkoba, alkohol, kafein, kurang olah raga, kolesterol tinggi (Endar S.dkk, 2015). Hasil dari Riskesdas pada tahun 2018 di Indonesia menyebutkan sebesar 63.309 .620 orang mengalami hipertensi. Di Provinsi Jawa Tengah, kejadian hipertensi sebanyak (15,14\%) lebih tinggi dibanding tahun 2017 yaitu (12,98\%) (Dinkes Provinsi Jawa Tengah, 2018).

Data Dinas Kesehatan Kabupaten Grobogan sepanjang tahun 2019 terdapat jumlah penderita hipertensi pada usia $>18$ tahun ditemukan sebanyak $(14,46 \%)$ dan minum obat antihipertensi sebanyak 7,02\% sedangkan sisanya menggunakan pengobatan secara tradisional (Dinkes Grobogan, 2019). Pada era modern ini telah banyak digunakan pengobatan secara tradisional yang diambil dari tanaman

\section{METODE}

Penelitian ini merupakan penelitian kuantitatif dengan rancangan quasy eksperimen with control group design. Variabel penelitian ini adalah variabel independen yaitu daun kelor dan variabel dependen yaitu tekanan darah tinggi pada penderita hipertensi.Tekanan darah diukur sebelum dan sesudah diberikan daun kelor sebanyak 30 responden, kemudian dibandingkan dengan kelompok kontrol dengan air hangat

\section{HASIL}

\section{Pengaruh Pemberian Daun Kelor Terhadap Penurunan Tekanan Darah (Sistole dan Diastole)}

Tabel 1 menunjukan hasil analisa wilcoxon test kelompok perlakuan pada tekanan darah sistole nilai mean sebelum diberikan intervensi adalah 164,33 mmHg dan setelah diberi intervensi adalah 148,33 mmHg. Terdapat yang ada di sekitar untuk pengobatan berbagai penyakit. Jenis tanaman obat yang telah terbukti berkhasiat dan jumlahnya sangat banyak dan dikenal dapat menurunkan tekanan darah adalah Moringa Oleifera Lam atau yang biasa disebut dengan kelor.

Daun kelor memiliki kandungan kalium yang tinggi, yaitu $259 \mathrm{mg}$ kalium / $100 \mathrm{~g}$ daun kelor, sedangkan kandungan natrium daun kelor yang relatif rendah bermanfaat dan aman bagi penderita hipertensi (Kintoko, 2018). Hipertensi adalah salah satu penyakit penyerta yang banyak di temukan pada penderita COVID-19, sekitar 15\% kasus hipertensi yang terdapat pada pasien COVID-19 (Chang T et all, 2020) dan kejadian hipertensi mayoritas terjadi pada usia lansia yaitu sebesar 54,60\% (Riskesdas 2018), dimana usia tersebut telah mengalami penurunan fungsi organ sehingga sangat beresiko untuk terjadi suatu penyakit. Berdasarkan fenomena tersebut, tujuan penelitian dilakukan untuk mengetahui pengaruh pemberian daun kelor terhadap penurunan tekanan darah pada penderita hipertensi lansia selama masa pandemi covid- 19 di Kabupaten Grobogan.

sebanyak 30 responden. Kriteria inklusi lansia dengan tekanan darah ringan sampai dengan sedang di wilayah Puskesmas Kradenan 1, tidak mengkonsumsi obat dan berada pada wilayah zona merah covid 19. Pengambilan sampel adalah non probability sampling dengan teknik qouta sampling (Judgement Sampling) dan diuji dengan wilcoxon untuk kelompok berpasangan sedangkan uji Mann Whitney untuk uji tidak berpasangan.

perbedaan nilai tekanan darah sistole sebelum dan setelah diberikan intervensi dengan $p$ value 0,000 . Sedangkan nilai mean tekanan diastole sebelum diberi intervensi adalah $103,33 \mathrm{mmHg}$ dan setelah diberikan intervensi adalah $89 \mathrm{mmHg}$. Terdapat perbedaan tekanan darah diastole sebelum dan setelah diberikan daun kelor dengan $p$ value 0,000 . 
Tabel 1. Pengaruh Pemberian Daun Kelor Terhadap Penurunan Tekanan Darah (Sistole dan Diastole) $(n=30)$

\begin{tabular}{lccc}
\hline \multicolumn{1}{c}{ Tekanan Darah Sistole } & Mean & SD & P value \\
\hline Pre Daun Kelor & 164,33 & 11,351 & \multirow{2}{*}{0,000} \\
Post Daun Kelor & 148,33 & 10,199 & \\
\hline \multicolumn{1}{c}{ Tekanan Darah Diastole } & & & \\
\hline Pre Daun Kelor & 103,33 & 7,112 & \multirow{2}{*}{0,000} \\
Post Daun Kelor & 89,00 & 7,589 & \\
\hline
\end{tabular}

2. Pengaruh Pemberian Air hangat Terhadap Penurunan Tekanan Darah (Sistole dan Diastole)

Berdasarkan tabel 2, diketahui bahwa uji statistik dengan menggunakan wilcoxon test kelompok kontrol pada tekanan darah Hipertensi baik sistole maupun diastole mengalami penurunan pada nilai rata-rata sebelum dan sesudah diberikan air hangat yaitu penurunan 4,67 pada sistole dan penurunan 4,00 pada diastole. Artinya ada perbedaan tekanan darah baik sistole maupun diastole sebelum dan sesudah pemberian air hangat. Nilai signifikansi dari perbedaan tersebut masing-masing didapatkan $\rho(0,000)<\alpha(0,05)$ pada taraf kepercayaan $95 \%$, maka dapat disimpulkan ada pengaruh pemberian air hangat terhadap penurunan tekanan darah pada lansia hipertensi di Kabupaten Grobogan.

Tabel 2. Pengaruh Pemberian Air hangat Terhadap Penurunan Tekanan Darah (Sistole dan Diastole)( $n=30)$

\begin{tabular}{llll}
\hline \multicolumn{1}{c}{ Tekanan Darah Sistole } & \multicolumn{1}{c}{ Mean } & SD & P value \\
\hline Pre kelompok kontrol & 163,00 & 12,635 & \multirow{2}{*}{0,001} \\
Post kelompok kontrol & 158,33 & 12,058 & \\
\cline { 1 - 2 } \multicolumn{1}{c}{ Tekanan Darah Diastole } & & & \\
\hline Pre kelompok kontrol & 103,00 & 6.513 & \multirow{2}{*}{0,001} \\
Post kelompok kontrol & 99,00 & 6.618 & \\
\hline
\end{tabular}

3. Perbedaan Pengaruh Pemberian Daun Kelor Terhadap Penurunan Tekanan Darah pada Kelompok perlakukan dengan Kelompok Kontrol

Berdasarkan tabel 3 diketahui nilai ratarata penurunan tekanan darah sistole pada kelompok perlakuan sebesar 16,00 dan pada kelompok kontrol 4,67 sedangkan rata-rata penurunan tekanan darah diastole pada kelompok perlakuan sebesar 14,33 dan kelompok kontrol sebesar 4,00. Artinya rata-rata penurunan tekanan darah baik sistole ataupun diastole pada kelompok perlakuan lebih besar dari pada kelompok kontrol. Berdasarkan nilai signifikansi didapatkan $p$ value 0,002 pada tekanan darah sistole dan $p$ value 0,000 pada tekanan darah diastole pada taraf kepercayaan 95\%, maka dapat disimpulkan ada perbedaan penurunan tekanan darah pada kelompok perlakuan dan kelompok kontrol pada lansia hipertensi di Kabupaten Grobogan.

Tabel 3. Perbedaan Pengaruh Pemberian Daun Kelor Terhadap Penurunan Tekanan Darah (Sistole dan Diastole) $(n=30)$

\begin{tabular}{llc}
\hline Tekanan darah sistole & Mean & P value \\
\hline Pre kelompok kelor & 16,00 & 0,002 \\
Post kelompok kontrol & 4,67 & P value \\
\hline Tekanan darah diastole & Mean & 0,000 \\
\hline Pre kelompok kelor & 14,33 & 0,00 \\
Post kelompok kontrol & 4,00 \\
\hline
\end{tabular}




\section{PEMBAHASAN}

Berdasarkan hasil penelitian yang sudah dilakukan yaitu pengukuran tekanan darah sistolik uji statistik dengan menggunakan wilcoxon test kelompok perlakuan pada tekanan darah Hipertensi baik sistole maupun diastole mengalami penurunan pada nilai rata-rata sebelum dan sesudah diberikan daun kelor yaitu penurunan 16,00 pada sistole dan penurunan 14,33 pada diastole. Artinya ada perbedaan tekanan darah baik sistole maupun diastole sebelum dan sesudah pemberian daun kelor. Nilai signifikansi dari perbedaan tersebut masing-masing didapatkan $\rho(0,000)<\alpha(0,05)$ pada taraf kepercayaan $95 \%$.

Menurut peneliti terdapat temuan dari hasil penelitian ada pengaruh yang signifikan dalam perlakuan pemberian daun kelor terhadap penurunan tekanan darah. Hal ini ditunjukkan berdasarkan perbedaan rata-rata pada pre dan post test perlakuan pemberian daun kelor sebesar (16,00 pada siastole dan 14,33 pada diastole), dan nilai signifikansi $p(0.000)<0.05$, maka Hipotesa diterima,artinya terdapat beda rata-rata antara pengukuran tekanan darah responden sebelum dan sesudah perlakuan pemberian daun kelor. Perbedaan dari hasil sebelum dan sesudah perlakuan dikarenakan didalam daun kelor tersebut terdapat kandungankandungan zat yang dapat menurunkan tekanan darah sehingga dapat menurunkan tekanan darah responden. Sedangkan dari hasil penelitian terhadap kelompok pemberian air hangat dengan menggunakan wilcoxon test kelompok kontrol pada tekanan darah Hipertensi baik sistole maupun diastole mengalami penurunan pada nilai rata-rata sebelum dan sesudah diberikan air hangat yaitu penurunan 4,67 pada sistole dan penurunan 4,00 pada diastole. Artinya ada perbedaan tekanan darah baik sistole maupun diastole sebelum dan sesudah pemberian air hangat. Nilai signifikansi dari perbedaan tersebut masing-masing didapatkan $\rho$ $(0,000)<\alpha(0,05)$ pada taraf kepercayaan 95\%, sehingga bisa di artikan bahwa air hangat pun mampu menurunkan tekanan darah pada lansia dengan hipertensi. Penurunan tekanan darah pada kelompok kontrol juga dipengaruhi oleh faktor pendidikan dimana ada beberapa responden dengan pendidikan sarjana.

Pernyataan ini sejalan dengan penelitian Sutrisno at al (2018), bahwa tingkat pendidikan memiliki pengaruh yang kuat terhadap perilaku pengendalian hipertensi. Hal ini sesuai dengan teori yang dikemukakan oleh John Dewey dalam Mahyuliansyah (2010), bahwa melalui pendidikan seseorang akan mempunyai kecakapan, mental dan emosional yang membantu seseorang untuk dapat berkembang mencapai tingkat kedewasaan. Tingkat pengetahuan semakin tinggi maka akan semakin bertambah pula kecakapannya, baik secara intelektual maupun emosional serta semakin berkembang pula pola pikir yang dimilikinya. Tinggi pendidikan seseorang maka mempengaruhi pengetahuan seseorang tentang hipertensi serta bahaya- bahaya yang timbul maka semakin tinggi pula partisipasi seseorang terhadap pengendalian hipertensi seperti penyediaan diet hipertensi dan gaya hidup yang sehat sehingga tekanan darah pada kelompok kontrol terjadi penurunan. Meskipun demikian rata rata penurunan tekanan darah lebih besar pada responden dengan pemberian daun kelor. Penurunan tekanan darah pada kelompok kontrol tidak bisa maksimal, bisa dipengaruhi oleh beberapa faktor. Faktor tesebut yaitu lansia menganggap bahwa air hangat tidak memiliki kandungan atau zatzat yang mampu menurunkan tekanan darah seperti daun kelor sehingga tidak maksimal dalam melakukan terapi pemberian air hangat.

Tekanan darah tinggi merupakan faktor risiko utama untuk serangan jantung. Arteri membawa oksigen dalam darah ke otot jantung. Nutrisi penting yang dibutuhkan oleh seseorang yang menderita tekanan darah tinggi ditemukan secara alami dalam tanaman Kelor. Arginine merupakan asam amino yang ditemukan dalam tanaman Kelor dan dikenal untuk menyeimbangkan tekanan darah. Kalsium, Magnesium, Kalium, Seng, dan Vitamin E juga ditemukan pada Kelor. Kelor mengandung seluruh nutrisi yang dibutuhkan untuk menyeimbangkan tekanan darah. Kalsium dibutuhkan untuk relaksasi otot polos dan kontraksi, peningkatan konsumsi kalsium dapat memiliki efek langsung pada pembuluh darah.Penelitian telah menemukan bahwa dibandingkan dengan suplemen, kalsium memiliki dua kali manfaat bagi tekanan darah. Kalsium dari sumber sintetik dapat menyebabkan batu ginjal. Kelor mengandung Kalsium 17 kali lebih banyak dibanding susu. Kelor mengandung kalium 15 kali lebih banyak dari pisang. Kandungan kalium yang tinggi cenderung menurunkan kandungan sodium. Kalium bekerja 
dengan cara meningkatkan ekskresi natrium dalam urin, yang membantu melebarkan pembuluh darah, dan mengubah interaksi hormon yang mempengaruhi tekanan darah.

Makanan yang mengandung magnesium tinggi sangat bermanfaat bagi penderita hipertensi, kemungkinan besar dengan berkontribusi terhadap relaksasi otot polos pembuluh darah. Kelor juga mengandung magnesium bersama dengan zinc dan vitamin $\mathrm{E}$ yang mengambil bagian dalam mengurangi tekanan darah bersama dengan nutrisi lainnya. Kelor mengandung $384 \mathrm{mg}$ magnesium dalam 100 gram tepung daun dan 2,2 kali lebih banyak bioavailable serta mengandung Zinc, 6 kali lebih banyak dibanding almond dan 6,46 kali lebih banyak diserap ke dalam darah (Wahyudi \& nurhaedah, 2017).

Daun kelor kaya akan postasium sehingga kadar sodium dalam darah dapat dikendalikan yang implikasinya pada penurunan tekanan darah tinggi. Kandungan fitosferol dalam daun kelor juga dapat menggantikan peran kolesterol jahat dalam darah. Dengan mengkosumsi daun kelor, aliran darah pun menjadi lancar sehingga resiko pengendapan zat-zat yang dapat mengakibatkan tekanan darah tinggi bisa di hindari. Disamping itu daun kelor kaya akan potassium sehingga kadar sodium dalam darah dapat dikendalikan yang implikasinya pada penurunan tekanan darah tinggi. Kandungan fitosterol dalam daun kelor juga dapat menggantikan peran kolesterol jahat dalam darah (Yanti, 2019). Penelitian Kintoko (2018), khasiat daun kelor sebagai antihipertensi ini karena daun kelor memiliki kandungan kalium yang tinggi, yaitu $259 \mathrm{mg} / 100 \mathrm{~g}$ daun kelor, sedangkan kandungan natrium daun kelor yang relatif rendah bermanfaat dan aman bagi penderita hipertensi, sehingga hal tersebut sangat efektif dalam pencegahan penyakit hipertensi.

Hal ini sejalan dengan penelitian Yanti (2019) yang menyebutkan adanya pengaruh pemberian rebusan daun kelor (moringa olifiera) terhadap tekanan darah pada penderita hipertensi dengan rata-rata tekanan darah pasien hipertensi sebelum diberikan air rebusan daun kelor dengan rata-rata sistolik 153,50 dan rata- rata diastolik 94,38 . Rata-rata tekanan darah pasien hipertensi sesudah diberikan air rebusan daun kelor dengan rata - rata sistolik 129,56 dan rata-rata diastolik 86,25. Terdapat pengaruh tekanan darah sistolik dan perbedaan diastolik dengan $p$ value $=0,000$. Sehingga berdasarkan penelitian tersebut dapat disimpulkan bahwa pemberian rebusan daun kelor (Moringa Olifiera) dapat berpengaruh untuk penurunan tekanan darah pada penderita hipertensi.

Menurut peneliti terdapat temuan dari hasil penelitian ada pengaruh yang signifikan untuk responden yang diberikan daun kelor terhadap penurunan tekanan darah. Hal ini ditunjukkan berdasarkan perbedaan rata-rata pada pre dan post test responden kelompok kelor sebesar $(164,33-148,33=16)$ pada siastole dan $(103,33$ - $89=14,33)$ pada diastole, dan nilai signifikansi $p(0.000)<0.05$, maka hipotesa diterima, artinya terdapat beda rata-rata antara pengukuran tekanan darah responden sebelum dan sesudah reponden diberikan daun kelor baik pada siastole maupun diastole. Perbedaan dari hasil sebelum dan sesudah pemberian daun kelor tersebut dapat disimpulkan bahwa pemberian daun kelor dapat menurunkan tekanan darah pada penderita hipertensi lansia meskipun pada kelompok kontrol dengan pemberian air hangat juga mengalami penurunan tekanan darah namun tidak sebesar nilai rata rata yang ada pada kelompok perlakuan dau kelor yaitu (163$158=4,67)$ pada siastole dan $(103-99=4)$ pada diastole, dan nilai signifikansi p $(0.000)<$ 0.01 ,

Hasil penelitian pengukuran tekanan darah sistolik dan diastolik yang sudah dilakukan menggunakan uji Mann-Whitney test mendapatkan hasil bahwa ada perbedaan yang signifikan antara perlakuan pemberian daun kelor dan responden dengan pemberian air hangat. Ini dibuktikan dengan perbedaan yang sangat signifikan pada rata-rata hasil siastole pada kelompok perlakuan pemberian daun kelor lebih besar yaitu 16,00 dari kelompok kontrol pemberian air hangat dengan rata rata 4,67. Begitu pula pada rata-rata penurunan tekanan darah diastole, pada kelompok perlakuan daun kelor lebih besar yaitu 14,33 sedangkan kelompok kontrol dengan air hangat 4,00 nilai 
signifikansi pemberian daun kelor sebesar $p$ ( 0.000 ) dan nilai signifikansi responden dengan pemberian air hangat sebesar $p(0.001)$.

Menurut peneliti melihat dari hasil data pre test dan post test yang didapatkan bahwa daun kelor lebih signifikan dalam proses penurunan tekanan darah. Karena pada penelitian ini respondennya adalah lansia dan responden ini lebih percaya terhadap daun kelor yang mengandung zat yang mampu menurunkan tekanan drah dari pada air hangat yang berwarna putih dengan asumsi lansia tidak mempunyai kandungan apapun Sehingga kelompok perlakuan meminum daun kelor secara teratur, berbeda dengan responden kelompok kontrol yang minum air hangat tidak teratur hanya sebatas untuk menghilangkan rasa haus., responden dari kelompok kontrol hanya meminum air hangat apabila responden tersebut merasakan keluhan saja sehingga tersugesti kalau minum air hangat akan merasa mudah berkeringat dan dengan keluarnya keringat lansia menganggap penyakitnya sudah teratasi. Berbeda dengan responden kelompok perlakuan yang meminum daun kelor dengan teratur sehingga dapat menurunkan tekanan darah dengan optimal.

Penelitian ini sesuai dengan penelitian yang dilakukan oleh (Ervina \& Ayubi, 2018)yang berjudul Peran Kepercayaan Terhadap Penggunaan Pengobatan Tradisional Pada Penderita Hipertensi Di Kota Bengkulu, hasil penelitian tersebut menemukan bahwa 68,4\% penderita hipertensi memiliki kepercayaan tinggi terhadap pengobatan tradisional. Sebanyak $55.8 \%$ responden percaya hipertensi bisa sembuh dengan cara pengobatan tradisional. Hal ini berbeda dengan penelitian di Yogyakarta, sebesar $75.7 \%$ penderita hipertensi percaya hipertensi bisa sembuh dengan melakukan pengobatan tradisional.

\section{KESIMPULAN}

Hasil pengukuran tekanan darah sistolik responden pada kelompok perlakuan pemberian daun kelor sebelum diberikan perlakuan pemberian daun kelor memiliki rata-rata 164,33 sedangkan pada kelompok kontrol yang meminum air hangat memiliki nilai rata-rata 163. Hasil dari sesudah dilakukan perlakuan dari kelompok perlakuan pemberian daun kelor memiliki rata-rata nilai sebesar 148,33, sedangkan pada kelompok kontrol pemberian air hangat memiliki nilai rata-rata sebesar 158,33.

Hasil pengukuran tekanan darah diastolik responden pada kelompok perlakuan pemberian daun kelor sebelum diberikan perlakuan pemberian daun kelor memiliki rata-rata 103,33 sedangkan pada kelompok kontrol yang meminum air hangat memiliki nilai rata-rata 103. Hasil dari sesudah dilakukan perlakuan dari kelompok perlakuan pemberian daun kelor memiliki rata-rata nilai sebesar 89,00 , sedangkan pada kelompok kontrol pemberian air hangat memiliki nilai rata-rata sebesar 99,00.

Ada perbedaan rata-rata pre dan post pada pengukuran tekanan darah sistolik dengan perlakuan pemberian daun kelor (164,33-148,33 $=16.00$ ) begitu pula pada tekanan darah diastolik dengan perlakuan pemberian daun kelor $(103,33-89=14,67)$ dengan demikian ada perbedaan yang bermakna antara pre dan post perlakuan pemberian daun kelor dengan nilai $p$ $(0.000)<(0.05)$. Sedangkan perbedaan rata-rata siastole pre dan post pada kelompok kontrol dengan pemberian air hangat $(163-158,33=$ 4,67) sedangkan diastolenya (103-99=4) dengan demikian ada perbedaan antara pre dan post kelompok kontrol responden dengan pemberian air hangat dengan nilai signifikansi $p(0.001)<$ (0.05)

Dari hasil tersebut terdapat perbedaan namun tidak signifikan antara sebelum dan sesudah responden dengan pemberian air hangat. Dari hasil pengukuran tekanan pre dan post yang sudah dilakukan dapat disimpulkan bahwa daun kelor dapat menurunkan tekanan darah sementara pemberian air hangat tidak. Uji beda dengan Mann-Whitney test antara pemberian daun kelor dan air hangat dengan nilai signifikansi sebesar (0.002) pada siastole dan 0,000 pada diastole, maka dapat disimpulkan ada perbedaan pengaruh antara perlakuan pemberiandaun kelor terhadap penurunan tekanan darah pada lansia hipertensi di masa pandemi covid -19 di Kabupaten Grobogan.

\section{REFERENSI}

Azizah. (2011). Keperawatan Lanjut Usia. Yogyakarta: Graha Ilmu. 
Cahyono, A. (2015). Hubungan Pengetahuan Tentang Hipertensi Dengan Sikap Perawatan Hipertensi Pada Pasien Hipertensi. Jurnal AKP, 6, 224-232. https://doi.org/10.26699/jnk.v5i3.ART.p224

Chang T, Wu J, Chang L. Since January 2020 Elsevier has created a COVID-19 resource centre with free information in English and Mandarin on the novel coronavirus COVID-research that is available on the COVID-19 resource centre -including this ScienceDirect Clinical characteris. J Formos Med Assoc. 2020;(January).

Dahlan,Sopiyudin.(2014). Statistik Untuk Kedokteran Dan Kesehatan Edisi 6. Jakarta: Salmba Medika.

Dahlan. (2011). Indonesia One Search. 2011. https://onesearch.id/Author/Home?author=Dahla $\mathrm{n} \% 2 \mathrm{C}+$ Sopiyudin

Diah, A. W. M., \& Jura, R. (2017). Uji AKtivitas Antioksidan Ekstrak Air dan Ekstrak Etanol Daun Kelor ( Moringa Oleifera LAM ) Antioxidant Activity Tests of Water and Ethanol Extracts of Moringa ( Moringa oleifera LAM ) Leaves. Jurnal Akademika Kimia, 6(May), 125-131.

Dinas Kesehatan Kabupaten Grobogan.(2019). Profil Kesehatan Kabupaten Grobogan. Grobogan

Dinkes Provinsi Jawa Tengah. (2018). Profil Kesehatan Provinsi Jawa Tengah.

Endar S.dkk, 2015. (2015). efektifitas relaksasi otot progresif terhadap tekanan darah pada penderita hipertensi esensial, 2(2).

Kemenkes RI.(2014). Profil Kesehatan Indonesia. Jakarta: Kementrian KesehatanRepublik Indonesia.

Kintoko. (2018). Fitoterapi Hipertensi dengan Daun Kelor. Jamu

Digital.
https://www.jamudigital.com/berita?id=Fitoterapi Hipertensi dengan Daun Kelor

Kreutz R, Algharably EAEH, Azizi M, et al. Hypertension, the renin-angiotensin system, and the risk of lower respiratory tract infections and lung injury: implications for COVID-19. Cardiovasc Res. 2020:1-12.doi:10.1093/cvr/cvaa0978.Guan W, Ni $Z$, $\mathrm{Hu} \mathrm{Y}$, et al. Clinical characteristics of coronavirus disease 2019 in China. N Engl J Med. 2020;382(18):1708-1720 doi:10.1056/NEJMoa2002032

Nuranti, Z., Maimaznah, M., \& Anggraini, A. A. (2020). Pengaruh Pendidikan Kesehatan dan Pemberian Daun Salam Pada Pasien Dengan Asam Urat di Wilayah RT 10 Kelurahan Murni. Jurnal Abdimas Kesehatan (JAK), 2(1), 50. https://doi.org/10.36565/jak.v2i1.90

Riskesdas. (2018). Laporan Provinsi Jawa Tengah Riskesdas 2018. https://dinkesjatengprov.go.id

Sherwood L. (2014). Fisiologi manusia dari sel ke sistem. 6th ed. Jakarta: EGC

Suprapto. (2014). Patologi Dan Patofisiologi Penyakit. Yogyakarta: Nuha Medika.

Sutrisno.,Widayanti,C.N \& Radate. (2018). "Hubungan Tingkat Pendidikan dan Sikap Terhadap Perilaku Pengendalian Hipertensi Pada Lansia Di Desa Jono Kecamatan Tawangharjo Kabupaten Grobogan". Ners. STIKES An Nuur Purwodadi.Purwodadi

Tarigan, A. R., \& Lubis, Z. (2018). Dukungan Keluarga Terhadap Diet Hipertensi di Desa Hulu Kecamatan Pancur Batu Tahun 2016. Jurnal Kesehatan, 11(1), 9-17. 